\title{
Synthesis of Novel Iono- and Photochromic Spiropyrans Derived from 6,7-Dihydroxy-8-Formyl-4-Methyl-2H-Chromene-2-One
}

\author{
Olga G. Nikolaeva, ${ }^{1}$ Alexey V. Tsukanov, ${ }^{2}$ Evgenii N. Shepelenko, ${ }^{2}$ Boris S. Lukyanov, ${ }^{1}$ \\ Anatoly V. Metelitsa, ${ }^{1}$ Olga Yu. Kostyrina, ${ }^{1}$ Alexander D. Dubonosov, ${ }^{2}$ Vladimir A. Bren, ${ }^{1}$ \\ and Vladimir I. Minkin ${ }^{1,2}$ \\ ${ }^{1}$ Institute of Physical and Organic Chemistry, Southern Federal University, 344090 Rostov on Don, Russia \\ ${ }^{2}$ Southern Scientific Center of Russian Academy of Sciences, 344006 Rostov on Don, Russia \\ Correspondence should be addressed to Olga G. Nikolaeva, dubon@ipoc.rsu.ru
}

Received 31 March 2009; Accepted 29 May 2009

Recommended by Mohamed Sabry Abdel-Mottaleb

\begin{abstract}
Novel photochromic spiropyrans (SPPs) containing 6'-hydroxy group were synthesized and their spectral properties as well as abilities for complexation with metal ions studied. In solutions they exist as equilibrium mixture of spirocyclic (A) and merocyanine (B) isomers. The largest content of merocyanine form was found for the derivative with an electron-donating methyl group in position 5 of hetaryl fragment. The irradiation of SPPs in acetonitrile shifts the equilibrium to the B form. Similar effect causes the addition of metal cations due to formation of colored complexes with merocyanine isomers.
\end{abstract}

Copyright ( 2009 Olga G. Nikolaeva et al. This is an open access article distributed under the Creative Commons Attribution License, which permits unrestricted use, distribution, and reproduction in any medium, provided the original work is properly cited.

\section{Introduction}

Design and synthesis of novel photochromic spiropyrans and spirooxazines (SPOs) displaying ionochromic properties are of significant interest due to their application as magnetic $[1,2]$, in devices of molecular electronics [3] and as effective photoswitchable chemosensors for metal cations [4-6]. The structure of the latter type compounds usually contains chelate [7-14], calixarene [15], or crown-ether ionophore groups $[16,17]$. The coordination of metal cations occurring via interaction with ligating centers located in the chromene part of a spiropyran (or spirooxazine) can lead to thermally or photochemically driven cleavage of the $\mathrm{C}_{\text {spiro }}-\mathrm{O}$ bond of the cyclic isomer followed by Z/E-isomerization to give the metastable colored merocyanine form. By contrast, the complexation with ionophore conjugated with the hetaryl fragment of a spiropyran (or spirooxazine) results in destabilization of the merocyanine form caused by electrostatic repulsion between a metal cation and the positively charged nitrogen atom in the hetaryl moiety $[18,19]$. We synthesized a series of novel SPPs containing $6^{\prime}$-hydroxy group in order to study their structure in solutions, photochromic properties, and ionochromic ability towards the alkali-earth and d-metal cations.

\section{Experimental}

${ }^{1} \mathrm{H}$ NMR spectra were recorded on Bruker WM-250 $(300 \mathrm{MHz})$ spectrometer using $\mathrm{CDCl}_{3}$ as solvent. The ${ }^{1} \mathrm{H}$ chemical shifts were calibrated using the signals of solvent residual protons $(\delta 7.25 \mathrm{ppm})$. IR spectra were measured in Nujol using a Specord 75IR spectrometer. UV-Vis absorption spectra were obtained in acetonitrile with a Cary-100 spectrophotometer. Irradiation of solutions was carried out by filtered light of a high-pressure mercury lamp DRSh $(250 \mathrm{~W})$ supplied with glass filter $\left(\lambda_{\mathrm{irr}}=365 \mathrm{~nm}\right)$.

\section{Results and Discussion}

3.1. Synthesis. The compound 6,7-Dihydroxy-8-formyl-4methyl-2H-chromene-2-one (2) was prepared by coupling 6,7-dihydroxy-4-methyl-2H-chromene-2-one with ethyl $\mathrm{N}$ $p$-methoxyphenylformimidate formed in situ from 4methoxyphenylamine and triethyl orthoformate followed by the hydrolysis of Schiff base (1) with diluted hydrochloric acid (Scheme 1). The spyropyrans (4) were synthesized by condensation of aldehyde (2) with corresponding $3 \mathrm{H}$ indolium perchlorates (3) in presence of triethylamine. 

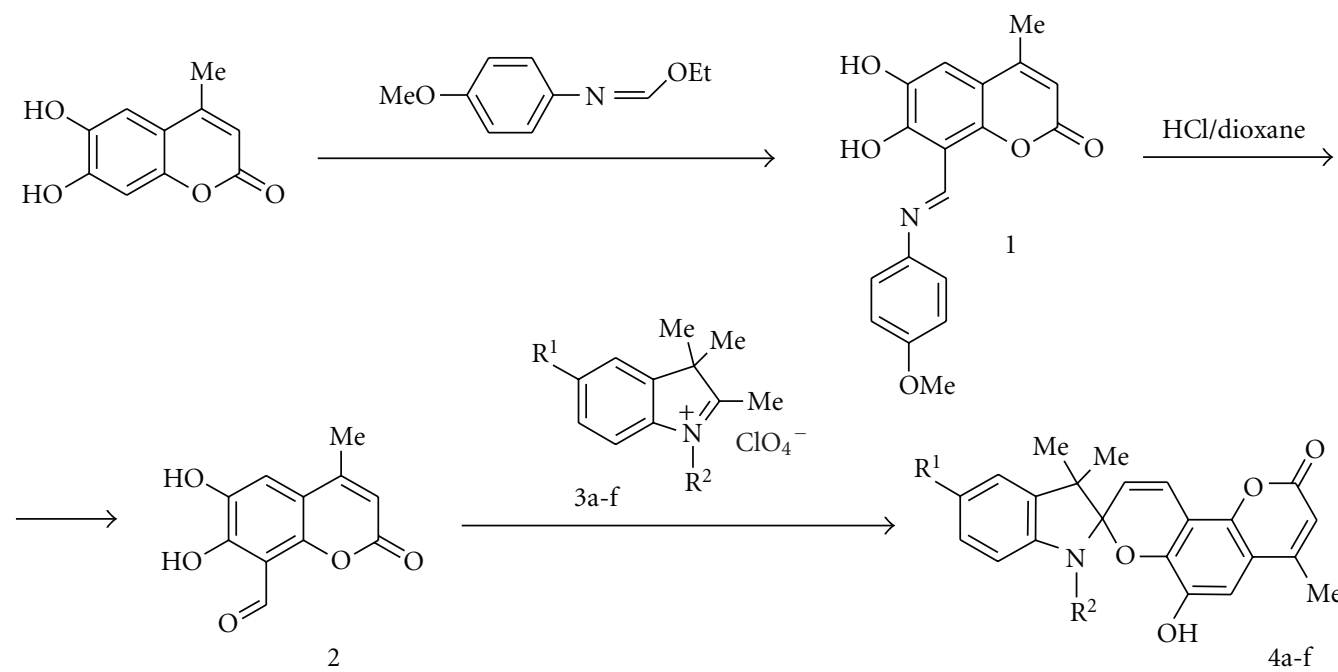

3, 4: $\mathrm{R}^{1}=\mathrm{H} ; \mathrm{R}^{2}=\mathrm{Me}(\mathrm{a}), \mathrm{C}_{8} \mathrm{H}_{17}$ (b), $\operatorname{Pr}^{i}(\mathrm{c}), \mathrm{CH}_{2} \mathrm{Ph}(\mathrm{d}) ;$

$\mathrm{R}^{1}=\mathrm{Me}, \mathrm{R}^{2}=\mathrm{Me}(\mathrm{e}) ; \mathrm{R}^{1}=\mathrm{NO}_{2}, \mathrm{R}^{2}=\mathrm{Me}(\mathrm{f})$

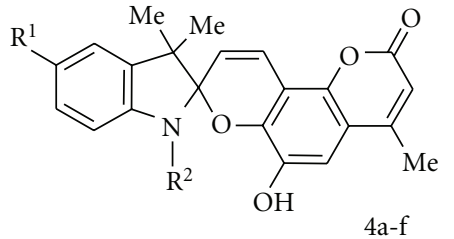

Scheme 1

(i) 6,7-dihydroxy-8-[(4-methoxyphenylimino)methyl]-4methylchromen-2-one (1). A mixture of $10 \mathrm{~g}$ (45 mmol) 6,7dihydroxy-4-methyl-2H-chromene-2-one, $11 \mathrm{~g}(90 \mathrm{mmol})$ 4-methoxyphenylamine, and $14 \mathrm{~mL}$ triethyl orthoformate was kept for 5 hours at $170^{\circ} \mathrm{C}$. The precipitate obtained after cooling was filtered and washed with ethanol. The crude product was purified by recrystallization from DMFA. Yield $25 \%$, mp $257-258^{\circ} \mathrm{C} .{ }^{1} \mathrm{H} \mathrm{NMR}\left(\mathrm{CDCl}_{3}\right): \delta 2.35\left(3 \mathrm{H}, \mathrm{s}, \mathrm{CH}_{3}\right)$, $3.88(3 \mathrm{H}, \mathrm{s}, \mathrm{OMe}), 6.06-7.43(7 \mathrm{H}, \mathrm{m}, \mathrm{Ar}-\mathrm{H}+\mathrm{OH}), 9.02(1 \mathrm{H}$, s, $\mathrm{CH}=), 15.70(1 \mathrm{H}, \mathrm{s}, \mathrm{OH})$. Anal.Calcd for $\mathrm{C}_{18} \mathrm{H}_{15} \mathrm{NO}_{5}$ : C, 66.46; H, 4.65; N, 4.31. Found: C, 66.36; H, 4.60; N, 4.41.

(ii) 6,7-dihydroxy-8-formyl-4-methyl-2H-chromene-2one (2). 6,7-Dihydroxy-8-[(4-methoxyphenylimino)methyl]4-methylchromen-2-one (1) (2.5 g, $7.7 \mathrm{mmol})$ was dissolved under heating in dioxane $(300 \mathrm{~mL})$ and $18 \% \mathrm{HCl}(150 \mathrm{~mL})$ was added. The solution obtained was allowed to stand 1015 minutes at $60-70^{\circ} \mathrm{C}$ and the reaction mixture was poured into the water $(500 \mathrm{~mL})$. The crude product was filtered, dried, and purified by recrystallization from 2-propanol. Yield $32 \%$, mp $234-235^{\circ} \mathrm{C} .{ }^{1} \mathrm{H}$ NMR $\left(\mathrm{CDCl}_{3}\right): \delta 2.40(3 \mathrm{H}, \mathrm{s}$, $\left.\mathrm{CH}_{3}\right), 5.64-7.35(3 \mathrm{H}, \mathrm{m}, \mathrm{Ar}-\mathrm{H}+\mathrm{OH}), 10.59(1 \mathrm{H}, \mathrm{s}, \mathrm{CHO})$, $12.42(1 \mathrm{H}, \mathrm{s}, \mathrm{OH})$. Anal.Calcd for $\mathrm{C}_{11} \mathrm{H}_{8} \mathrm{O}_{5}: \mathrm{C}, 60.01 ; \mathrm{H}$, 3.66. Found: C, $60.15 ; \mathrm{H}, 3.58$.

(iii) spiropyrans $(4 a-f)$ (general procedure). A mixture of corresponding perchlorate (3) $(1 \mathrm{mmol})$, aldehyde (2) $(1.1 \mathrm{mmol})$ and $0.1 \mathrm{~mL}(0.7 \mathrm{mmol})$ triethylamine was refluxed in 2-propanol $(20 \mathrm{~mL})$ for 5 hours. The solvent was removed, the residue was purified by column chromatography on $\mathrm{SiO}_{2}$ with chloroform as an eluent and recrystallized from 2-propanol.

(iv) 6' -hydroxy-1,3,3,4'-tetramethylspiro[indoline-2, $8^{\prime}$ pyrano[2,3-f]benzopyran]-2' $\left(7^{\prime} H\right)$-one (4a). Yield $24 \%, \mathrm{mp}$ 208-209 ${ }^{\circ} \mathrm{C}$; IR $\left(\nu_{\max } / \mathrm{cm}^{-1}\right.$, nujol): $3120,1685,1580,1560$, 920. ${ }^{1} \mathrm{H} \mathrm{NMR}\left(\mathrm{CDCl}_{3}\right): \delta$ isomer A $1.20,1.30(6 \mathrm{H}, \mathrm{s}+\mathrm{s}, 2$ gem- $\left.\left(\mathrm{CH}_{3}\right)_{2}\right), 2.34\left(3 \mathrm{H}, \mathrm{s}, \mathrm{CH}_{3}\right), 2.77\left(3 \mathrm{H}, \mathrm{s}, \mathrm{NCH}_{3}\right), 5.35$

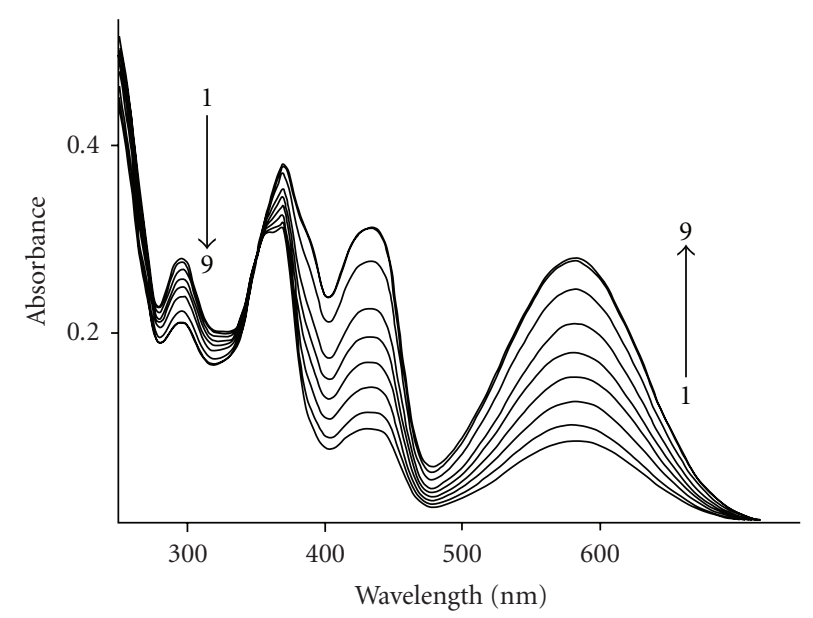

FIgURE 1: Absorption spectra of (4a) in acetonitrile solution before irradiation (1); after 15 seconds (2); 45 seconds (3); 90 seconds (4); 150 seconds (5); 180 seconds (6); 8 minutes (7); 16 minutes $(8) ; 26$ minutes (9) of irradiation $\left(\lambda_{\text {irr }}=365 \mathrm{~nm}, \mathrm{C}=2.5 \cdot 10^{-5} \mathrm{M}\right)$.

(1H, br. s, OH), $5.84\left(1 \mathrm{H}, \mathrm{d}, \mathrm{H}^{9 \prime}, J 10.5\right), 6.16\left(1 \mathrm{H}, \mathrm{s}, \mathrm{H}^{3 \prime}\right)$, 6.58-7.22 (5H, m, Ar-H), $7.47\left(1 \mathrm{H}, \mathrm{d}, \mathrm{H}^{10 \prime}, J\right.$ 10.5). Isomer B: $1.84\left(6 \mathrm{H}, \mathrm{s}, 2\right.$ gem- $\left.\left(\mathrm{CH}_{3}\right)_{2}\right), 2.31\left(3 \mathrm{H}, \mathrm{s}, \mathrm{CH}_{3}\right), 3.78(3 \mathrm{H}$, s, $\left.\mathrm{NCH}_{3}\right), 5.98\left(1 \mathrm{H}, \mathrm{s}, \mathrm{H}^{3 \prime}\right), 6.16-7.22(5 \mathrm{H}, \mathrm{m}, \mathrm{Ar}-\mathrm{H}), 8.47$ $(1 \mathrm{H}, \mathrm{d}, \mathrm{CH}=, J 14.8), 8.92(1 \mathrm{H}, \mathrm{d}, \mathrm{CH}=, J 14.8)$. Ratio of isomers A : B (see Table 1). Anal.Calcd for $\mathrm{C}_{23} \mathrm{H}_{21} \mathrm{NO}_{4}$ : C, 73.58; H, 5.64; N, 3.73. Found: C, 73.41; H, 5.65; N, 3.82.

(v) 6'-hydroxy-1-octyl-3,3,4'-trimethylspiro[indoline2,8'-pyrano[2,3-f]benzopyran]-2' $\left(7^{\prime} H\right)$-one (4b). Yield 27\%, mp $145-146^{\circ} \mathrm{C}$; IR $\left(\nu_{\max } / \mathrm{cm}^{-1}\right.$, nujol): $3180,1685,1610$, $1560,920 .{ }^{1} \mathrm{H}$ NMR $\left(\mathrm{CDCl}_{3}\right): \delta$ isomer A: $1.19-1.93(21 \mathrm{H}$, $\left.\mathrm{m}, 3 \mathrm{CH}_{3}+6 \mathrm{CH}_{2}\right), 2.34(3 \mathrm{H}, \mathrm{s}, \mathrm{Me}), 3.17\left(2 \mathrm{H}, \mathrm{m}, \mathrm{NCH}_{2}\right)$, $5.30\left(1 \mathrm{H}\right.$, br. s, OH), $5.81\left(1 \mathrm{H}, \mathrm{d}, \mathrm{H}^{9 \prime}, J 10.5\right), 6.17(1 \mathrm{H}, \mathrm{s}$, 


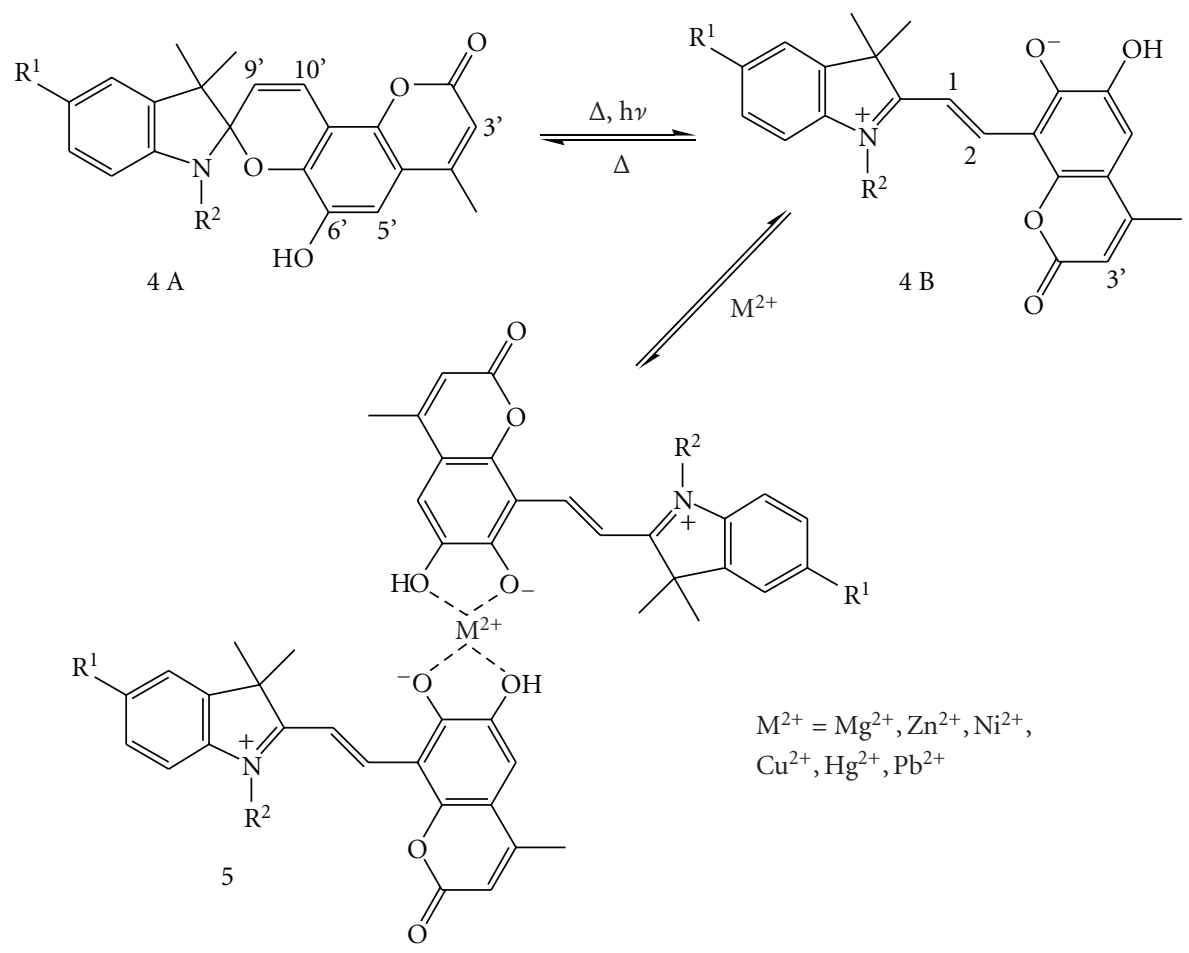

SCHEME 2

$\left.\mathrm{H}^{3 \prime}\right), 6.58-7.45\left(6 \mathrm{H}, \mathrm{m}, \mathrm{Ar}-\mathrm{H}+\mathrm{H}^{10 \prime}\right)$. Isomer B: 1.19-1.93 $\left(21 \mathrm{H}, \mathrm{m}, 3 \mathrm{CH}_{3}+6 \mathrm{CH}_{2}\right), 2.30(3 \mathrm{H}, \mathrm{s}, \mathrm{Me}), 4.18(2 \mathrm{H}, \mathrm{t}$, $\left.\mathrm{NCH}_{2}\right), 5.96\left(1 \mathrm{H}, \mathrm{s}, \mathrm{H}^{3 \prime}\right), 6.58-7.45(5 \mathrm{H}, \mathrm{m}, \mathrm{Ar}-\mathrm{H}), 8.70$ $(1 \mathrm{H}$, br. s, $\mathrm{CH}=), 8.92(1 \mathrm{H}, \mathrm{d}, \mathrm{CH}=, J 15.3)$. Ratio of isomers A : B is (see Table 1). Anal.Calcd for $\mathrm{C}_{30} \mathrm{H}_{35} \mathrm{NO}_{4}$ : C, 76.08; H, 7.45; N, 2.96. Found: C, 76.18; H, 7.48; N, 2.87.

(vi) 6'-hydroxy-1-isopropyl-3,3,4'-trimethylspiro[indoline-2,8' - pyrano[2,3-f]benzopyran]-2' $\left(7^{\prime} H\right)$-one (4c). Yield $68 \%, \mathrm{mp} 214-215^{\circ} \mathrm{C}$; IR $\left(\nu_{\max } / \mathrm{cm}^{-1}\right.$, nujol): 3160,1685 , $1660,1615,1580,920 .{ }^{1} \mathrm{H}$ NMR $\left(\mathrm{CDCl}_{3}\right): \delta$ isomer A: $1.18-1.83(12 \mathrm{H}, \mathrm{m}, 4 \mathrm{Me}), 2.34\left(3 \mathrm{H}, \mathrm{s}, \mathrm{CH}_{3}\right), 3.84(1 \mathrm{H}, \mathrm{m}$, $\mathrm{CH}), 5.42\left(1 \mathrm{H}\right.$, br. s, OH), $5.81\left(1 \mathrm{H}, \mathrm{d}, \mathrm{H}^{9 \prime}, J 10.6\right), 6.16$ $\left(1 \mathrm{H}, \mathrm{s}, \mathrm{H}^{3 \prime}\right), 6.77-7.41(5 \mathrm{H}, \mathrm{m}, \mathrm{Ar}-\mathrm{H}), 7.44\left(1 \mathrm{H}, \mathrm{d}, \mathrm{H}^{10^{\prime}}\right.$, $J$ 10.6). Isomer B: $1.18-1.83\left(12 \mathrm{H}, \mathrm{m}, 4 \mathrm{CH}_{3}\right), 2.31(3 \mathrm{H}, \mathrm{s}$, $\mathrm{Me}), 4.02(1 \mathrm{H}, \mathrm{m}, \mathrm{CH}), 5.01(1 \mathrm{H}$, br. $\mathrm{s}, \mathrm{OH}), 5.96(1 \mathrm{H}, \mathrm{s}$, $\left.\mathrm{H}^{3 \prime}\right), 6.77-7.41(5 \mathrm{H}, \mathrm{m}, \mathrm{Ar}-\mathrm{H}), 8.80(1 \mathrm{H}$, br. s, $\mathrm{CH}=), 8.92$ $(1 \mathrm{H}, \mathrm{d}, \mathrm{CH}=, J 14.3)$. Ratio of isomers A : B (see Table 1). Anal.Calcd for $\mathrm{C}_{25} \mathrm{H}_{25} \mathrm{NO}_{4}$ : C, 74.42; $\mathrm{H}, 6.25 ; \mathrm{N}, 3.47$. Found: C, 74.35; H, 6.39; N, 3.40.

(vii) 6'-hydroxy-1-benzyl-3,3,4'-trimethylspiro[indoline2,8'-pyrano[2,3-f]benzopyran]-2' $\left(7^{\prime} H\right)$-one (4d). Yield 31\%, mp 216-217 ${ }^{\circ} \mathrm{C}$; IR $\left(\nu_{\max } / \mathrm{cm}^{-1}\right.$, nujol): $3150,1670,1630$, 1570, 928. ${ }^{1} \mathrm{H}$ NMR $\left(\mathrm{CDCl}_{3}\right): \delta$ isomer A: $1.31,1.34(6 \mathrm{H}$, $\left.\mathrm{s}+\mathrm{s}, 2 \mathrm{gem}-\left(\mathrm{CH}_{3}\right)_{2}\right), 2.35\left(3 \mathrm{H}, \mathrm{s}, \mathrm{CH}_{3}\right), 4.21\left(1 \mathrm{H}, \mathrm{d}, \mathrm{CH}_{2}\right.$, $J$ 16.7), $4.63\left(1 \mathrm{H}, \mathrm{d}, \mathrm{CH}_{2}, J 16.7\right), 5.40(1 \mathrm{H}$, br. s, $\mathrm{OH}), 5.89$ $\left(1 \mathrm{H}, \mathrm{d}, \mathrm{H}^{9 \prime}, J 10.7\right), 6.16\left(1 \mathrm{H}, \mathrm{s}, \mathrm{H}^{3 \prime}\right), 6.37-7.55(11 \mathrm{H}, \mathrm{m}, \mathrm{Ar}-$ $\left.\mathrm{H}+\mathrm{H}^{10^{\prime}}\right)$. Isomer B: $\left.1.25\left(6 \mathrm{H}, \mathrm{s}, 2 \mathrm{gem}-\left(\mathrm{CH}_{3}\right)_{2}\right),\right), 1.89(2 \mathrm{H}$, s, $\left.\mathrm{NCH}_{2}\right), 5.53(1 \mathrm{H}$, br. s, OH $), 6.16\left(1 \mathrm{H}, \mathrm{s}, \mathrm{H}^{3 \prime}\right), 6.37-7.55$ $(10 \mathrm{H}, \mathrm{m}, \mathrm{Ar}-\mathrm{H}), 8.49(1 \mathrm{H}$, br. $\mathrm{s}, \mathrm{CH}=), 8.93(1 \mathrm{H}, \mathrm{d}, \mathrm{CH}=$, $J$ 15.3). Ratio of isomers A : B (see Table 1). Anal.Calcd for $\mathrm{C}_{29} \mathrm{H}_{25} \mathrm{NO}_{4}$ : C, 77.14; H, 5.58; N, 3.10. Found: C, 77.07; H, 5.52; N, 3.19.

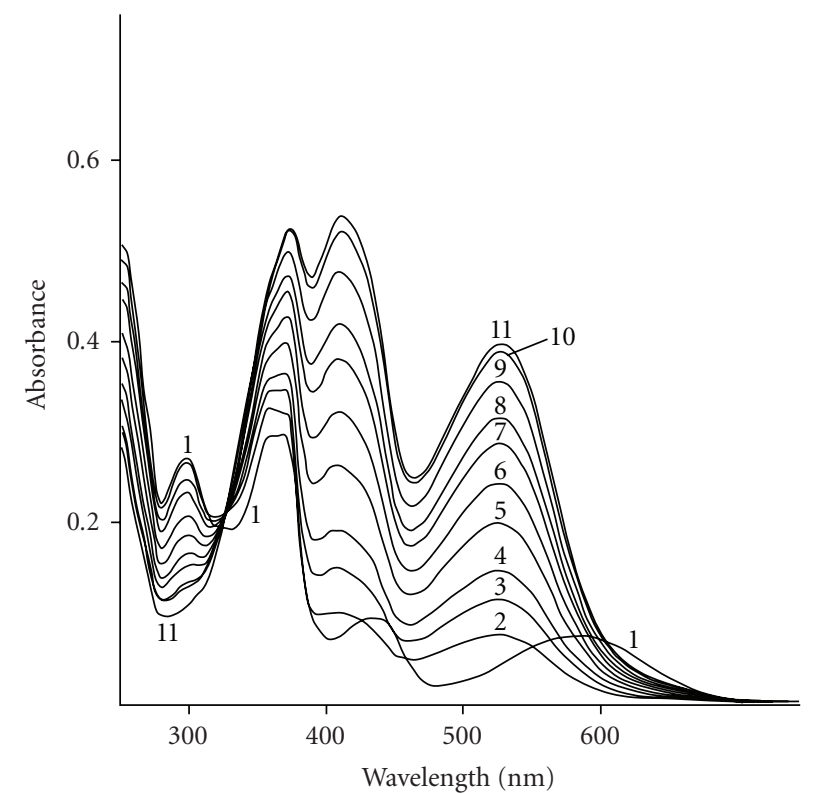

FIgURE 2: Absorption spectra of (4a) in dark conditions in acetonitrile solution before (1) and after addition of $\mathrm{Mg}\left(\mathrm{ClO}_{4}\right)_{2}(2)$; after 5 minutes (3); 10 minutes (4); 20 minutes (5); 30 minutes (6); 45 minutes (7); 60 minutes (8); 90 minutes (9); 120 minutes (10), 180 minutes $(11)\left([4 \mathrm{a}]=2.5 \times 10^{-5} \mathrm{M},\left[\mathrm{Mg}^{2+}\right]=5 \times 10^{-4} \mathrm{M}\right)$.

(viii) $\quad 6^{\prime}$-hydroxy-1,3,3,5,4'-pentamethylspiro[indoline2,8'-pyrano[2,3-f]benzopyran]-2' $\left(7^{\prime} H\right)$-one $(4 e)$. Yield $29 \%$, $\mathrm{mp} 276-277^{\circ} \mathrm{C}$; IR $\left(\nu_{\max } / \mathrm{cm}^{-1}\right.$, nujol): $3170,1685,1610$, 1570, 920. ${ }^{1} \mathrm{H}$ NMR $\left(\mathrm{CDCl}_{3}\right): \delta$ isomer A: $1.20,1.28(6 \mathrm{H}$, 


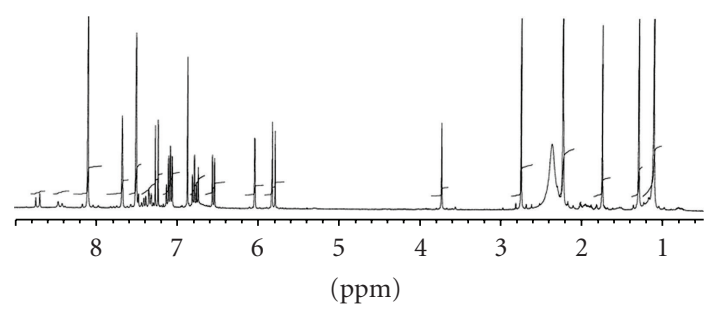

(a)

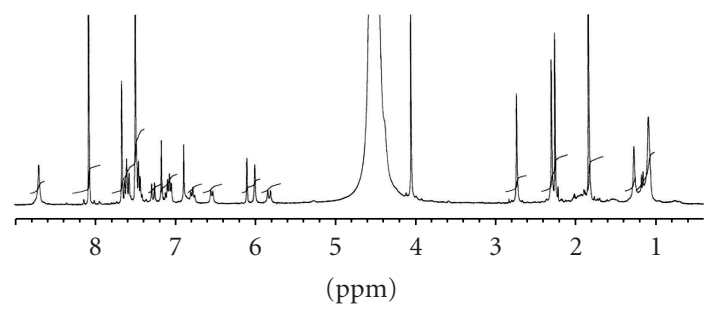

(b)

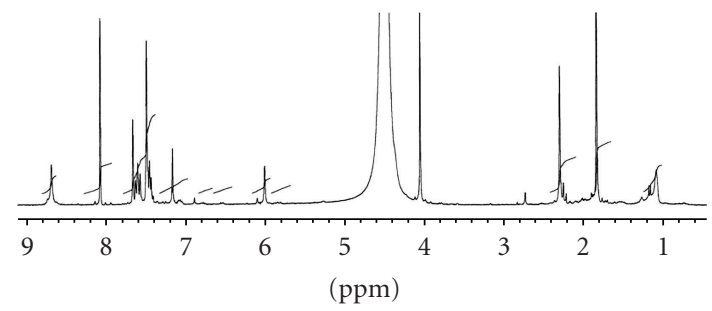

(c)

Figure 3: (a) ${ }^{1} \mathrm{H}$ NMR spectra of (4a) in dark conditions in $\mathrm{CD}_{3} \mathrm{CN}$-nitrobenzene- $d_{6}(1: 1 \mathrm{v} / \mathrm{v})$ and $(\mathrm{b})$ in presence of $\mathrm{Mg}\left(\mathrm{ClO}_{4}\right)_{2} \cdot 3 \mathrm{H}_{2} \mathrm{O}$ after 10 minutes; (c) 1 hour $\left(\nu_{\mathrm{Mg}^{2+}} / \nu_{(4 \mathrm{a})}=5\right)$.

$\mathrm{s}+\mathrm{s}, 2$ gem- $\left.\left(\mathrm{CH}_{3}\right)_{2}\right), 2.35\left(3 \mathrm{H}, \mathrm{s}, \mathrm{CH}_{3}\right), 2.48\left(3 \mathrm{H}, \mathrm{s}, \mathrm{CH}_{3}\right)$, $2.73\left(3 \mathrm{H}, \mathrm{s}, \mathrm{NCH}_{3}\right), 5.38\left(1 \mathrm{H}\right.$, br. s, OH) $5.84\left(1 \mathrm{H}, \mathrm{d}, \mathrm{H}^{9 \prime}\right.$, J 10.7), $6.15\left(1 \mathrm{H}, \mathrm{s}, \mathrm{H}^{3 \prime}\right), 6.44-7.31(4 \mathrm{H}, \mathrm{m}, \mathrm{Ar}-\mathrm{H}), 7.46$ $\left(1 \mathrm{H}, \mathrm{d}, \mathrm{H}^{10 \prime}, J\right.$ 10.7). Isomer B: $1.25\left(6 \mathrm{H}, \mathrm{s}, 2 \mathrm{gem}\left(\mathrm{CH}_{3}\right)_{2}\right)$, 1.83 (6H, s, Me), 2.33 (3H, s, Me), 3.85 (3H, s, NMe), 5.99 $\left(1 \mathrm{H}, \mathrm{s}, \mathrm{H}^{3 \prime}\right), 6.44-7.31(4 \mathrm{H}, \mathrm{m}, \mathrm{Ar}-\mathrm{H}), 8.43(1 \mathrm{H}, \mathrm{d}, \mathrm{CH}=, J$ 15.1), $8.85(1 \mathrm{H}, \mathrm{d}, \mathrm{CH}=, J 15.1)$. Ratio of isomers A : B (see Table 1). Anal.Calcd for $\mathrm{C}_{24} \mathrm{H}_{23} \mathrm{NO}_{4}$ : C, 74.02; $\mathrm{H}, 5.95 ; \mathrm{N}$, 3.60. Found: C, 74.19; H, 5.91; N, 3.55.

(ix) 6'-hydroxy-5-nitro-1,3,3,4' -tetramethylspiro[indoline-2,8'-pyrano[2,3-f]benzopyran]-2' $\left(7^{\prime} H\right)$-one (4f). Yield $25 \%, \mathrm{mp} 281-282^{\circ} \mathrm{C}$; IR $\left(\nu_{\max } / \mathrm{cm}^{-1}\right.$, nujol): 3170, 1700, $1600,1560,970 .{ }^{1} \mathrm{H}$ NMR $\left(\mathrm{CDCl}_{3}\right): \delta$ isomer A: $1.24,1.37$ $\left(6 \mathrm{H}, \mathrm{s}+\mathrm{s}, 2 \mathrm{gem}-\left(\mathrm{CH}_{3}\right)_{2}\right), 2.36\left(3 \mathrm{H}, \mathrm{s}, \mathrm{CH}_{3}\right), 2.90(3 \mathrm{H}, \mathrm{s}$, $\left.\mathrm{NCH}_{3}\right), 5.36(1 \mathrm{H}, \mathrm{s}, \mathrm{OH}), 5.82\left(1 \mathrm{H}, \mathrm{d}, \mathrm{H}^{9 \prime}, \mathrm{J} 10.5\right), 6.19$ $\left(1 \mathrm{H}, \mathrm{s}, \mathrm{H}^{3 \prime}\right), 6.55-8.18\left(6 \mathrm{H}, \mathrm{m}, \mathrm{Ar}-\mathrm{H}+\mathrm{H}^{10 \prime}\right)$. Anal.Calcd for $\mathrm{C}_{23} \mathrm{H}_{20} \mathrm{~N}_{2} \mathrm{O}_{6}$ : C, 65.71; H, 4.79; N, 6.66. Found: C, 65.70; H, $4.68 ; \mathrm{N}, 6.78$.

3.2. Spectral Properties and Complexation with Metal Ions. Electronic absorption spectra of SPP (4f) in toluene, chloroform, and acetonitrile show broad absorption bands at 295 and $365 \mathrm{~nm}$. For compounds (4a-e), the spectra contain also additional long-wavelength bands with maxima centered around 430 and $580 \mathrm{~nm}$ (Tables 1 and 2, Figure 1). For

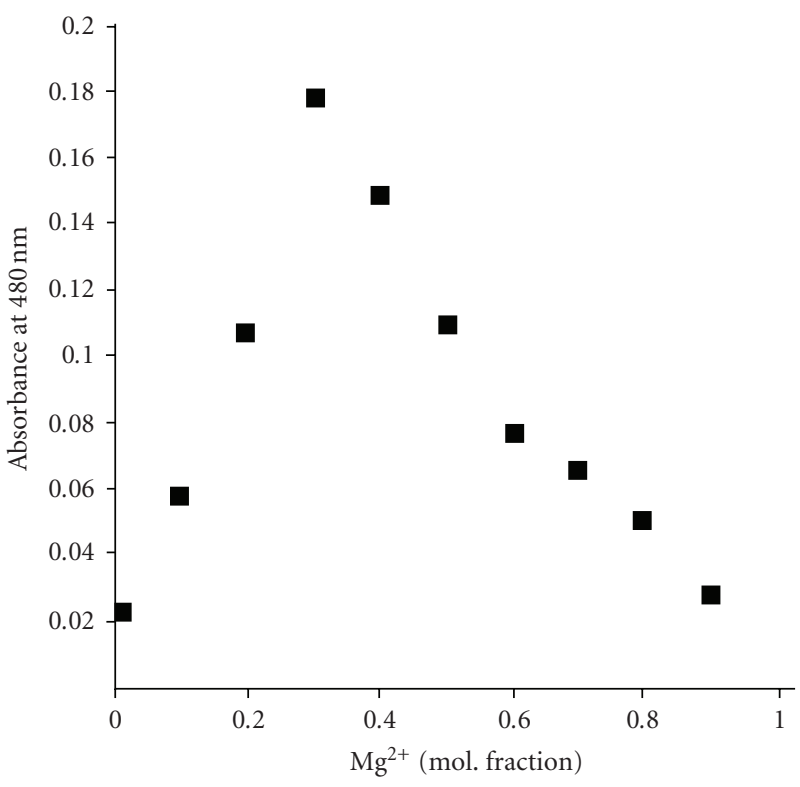

Figure 4: Continuous variation plot of the $(4 \mathrm{a}) / \mathrm{Mg}^{2+}([4 \mathrm{a}]+$ $\left.\left[\mathrm{Mg}^{2+}\right]=5 \times 10^{-5} \mathrm{M}\right)$ in acetonitrile.

SPPs (4a-e), the appearance of long-wavelength bands is accompanied by the additional proton signals of merocyanine isomers $\mathrm{B}$ in the ${ }^{1} \mathrm{H}$ NMR spectra. The longwavelength bands in absorption spectra of cyclic $\left({ }^{\mathrm{A}} \lambda_{\max }^{\mathrm{abs}}=\right.$ $370-371 \mathrm{~nm}$ ) and merocyanine ( $\left.{ }^{\mathrm{A}} \lambda_{\max }^{\mathrm{abs}}=580-650 \mathrm{~nm}\right)$ forms correspond to $\mathrm{S}_{0} \rightarrow \mathrm{S}_{1}$ transitions while the absorption bands of the cyclic form ( ${ }^{\mathrm{A}} \lambda_{\max }^{\mathrm{abs}}=294-299 \mathrm{~nm}$ ) and merocyanine form ( ${ }^{\mathrm{A}} \lambda_{\max }^{\mathrm{abs}}=456-471 \mathrm{~nm}$ ) correspond to $\mathrm{S}_{0} \rightarrow \mathrm{S}_{2}$ transitions (Table 2). According to ${ }^{1} \mathrm{H}$ NMR and absorption spectroscopy data only SPP (4f) with an electronwithdrawing $\mathrm{NO}_{2}$-group exists in solution of chloroform entirely as the cyclic form A, while the solutions of (4ae) contain both spirocyclic A and merocyanine B isomers (Scheme 2). The percentage of the merocyanine form in the equilibrium mixture was estimated using ${ }^{1} \mathrm{H}$ NMR data (Table 1). The largest content of form B is observed for the derivative (4e) with an electron-donating methyl group in position 5 .

The irradiation of SPPs $(4 \mathrm{a}-\mathrm{f})$ in acetonitrile $\left(\lambda_{\text {irr }}=\right.$ $365 \mathrm{~nm}$ ) leads to increase in intensity of the long-wavelength absorption band in the regions of 430-471 and 580-653 nm due to the formation of merocyanine form which is thermally converted to the ring-closed isomer A (Figure 1).

Lifetimes of the photoinduced absorption bands of forms $B$ allow to evaluate their thermal stability because content of merocyanine isomers in the equilibrium state in low-polarity solvent is substantially less than that of the cyclic isomers. Therefore, relaxation process rate constant is determined by the rate constant for the $\mathrm{B} \rightarrow$ A reaction. The lowest lifetime of the photoinduced absorption was observed for compound (4f) with an electron-withdrawing group in 5th position and the highest lifetime for the compound (4e) with an electron donating group (Table 2). Analogous results were previously obtained for the spirooxazines [20]. 
TABLe 1: Long-wavelength maxima of (4) and parameters of (4A)-(4B) equilibrium in chloroform at $293 \mathrm{~K}$.

\begin{tabular}{lccc}
\hline Comp. & $\begin{array}{c}\text { Absorption of }(4), \lambda_{\max },(\mathrm{nm}), \\
\left(\varepsilon \times 10^{-4}, 1 \mathrm{~mol}^{-1} \mathrm{~cm}^{-1}\right)\end{array}$ & Content of form B,\% & $K^{o}=[\mathrm{B}] /[\mathrm{A}]$ \\
\hline $4 \mathrm{a}$ & $448(2.31), 595(1.72)$ & 28.6 & 0.401 \\
$4 \mathrm{~b}$ & $447(2.35), 595(1.78)$ & 56.5 & 1.299 \\
$4 \mathrm{c}$ & $447(2.40), 596(1.82)$ & 23.5 & 0.307 \\
$4 \mathrm{~d}$ & $452(3.07), 605(2.04)$ & 63.0 & 0.099 \\
$4 \mathrm{e}$ & $448(1.85), 593(1.63)$ & 0 & 1.702 \\
$4 \mathrm{f}$ & - & - & - \\
\hline
\end{tabular}

TABLE 2: Spectral characteristics of isomers A, B for $(4 a-f)$ and lifetimes for photoinduced absorption in toluene at $293 \mathrm{~K}$.

\begin{tabular}{lccc}
\hline Comp. & ${ }^{\mathrm{A}} \lambda_{\max }^{\text {abs }},(\mathrm{nm})$ & ${ }^{\mathrm{B}} \lambda_{\max }^{\mathrm{abs}},(\mathrm{nm})$ & $\tau, \mathrm{s}$ \\
\hline 4a & $295,354,370$ & 458,614 & 161 \\
4b & $298,355,371$ & 459,617 & 205.7 \\
4c & $294,354 \mathrm{sh}, 370$ & 456,619 & 170.9 \\
4d & $295,354,370$ & 461,617 & 44.1 \\
4e & $299,356,370$ & 459,614 & 257.7 \\
4f & $299,355 \mathrm{sh}, 371$ & 471,653 & 6.5 \\
\hline
\end{tabular}

Under dark conditions, addition of metal cations: $\mathrm{Mg}^{2+}$ (as perchlorate), $\mathrm{Zn}^{2+}, \mathrm{Ni}^{2+}, \mathrm{Cu}^{2+}, \mathrm{Hg}^{2+}, \mathrm{Pd}^{2+}$ (as acetates) shifts the equilibrium to the open form $\mathrm{B}$ with increase in the maximum of absorption band in the visible region due to the formation of complexes (5) (Figure 2). Position of the absorption maxima of these bands depends on the nature of the metal ion. For example, complex (4a) with $\mathrm{Mg}^{2+}$ is characterized by absorption bands at 369,406 , and $524 \mathrm{~nm}$; with $\mathrm{Zn}^{2+}$ at 387,440 , and $550 \mathrm{~nm}$; with $\mathrm{Hg}^{2+}$ at $(372,455$, and $586 \mathrm{~nm})$. The maxima of these absorption bands are hypsochromically shifted with respect to the free merocyanine absorption. The content of the complexes (5) is greatly raised under exposure of the solution to UV light $\left(\lambda_{\text {irr }}=365 \mathrm{~nm}\right)$.

The structure of complexes (5) was estimated by IR spectroscopy. The IR-spectra of initial compounds contain broad absorption band of the hydroxyl group at 3100$3200 \mathrm{~cm}^{-1}$ which slightly changes after complex formation, so the substitution of hydroxyl group protons was excluded.

${ }^{1} \mathrm{H}$ NMR, IR spectrometry and the spectrophotometric titration method were employed for the analysis of the complexation processes. The ${ }^{1} \mathrm{H}$ NMR spectral changes for (4a) upon the addition of $\mathrm{Mg}^{2+}$ ions in $\mathrm{CD}_{3} \mathrm{CN} /$ nitrobenzene- $d_{6}$ $(1: 1 \mathrm{v} / \mathrm{v})$ solution are shown in Figure 3.

In a metal-free solution, signals of both spiro- and merocyanine forms are present in the spectrum. This spectrum is characterized by a doublet centered at $\delta 5.80 \mathrm{ppm}$ for the proton $(4 \mathrm{~A})-\mathrm{H}^{9 \prime}$, singlet at $\delta 6.1 \mathrm{ppm}$ for the proton $(4 \mathrm{~A})-\mathrm{H}^{3 \prime}$ and two doublets at $\delta 8.4 \mathrm{ppm}$ and $8.7 \mathrm{ppm}$ for the protons $(4 \mathrm{~B})-\mathrm{H}^{1},(4 \mathrm{~B})-\mathrm{H}^{2}$. The content of merocyanine isomer $B$ was estimated as $\sim 16 \%$. In the presence of metal sault chemical shifts of protons did not change significantly. After addition of $\mathrm{Mg}\left(\mathrm{ClO}_{4}\right)_{2} \cdot 3 \mathrm{H}_{2} \mathrm{O}$ in darkness the appearance of a resonance signal at $6.00 \mathrm{ppm}$ for the proton $(4 \mathrm{~B})-\mathrm{H}^{3 \prime}$ and substantial increase in the intensity of multiplet at $\delta 8.70 \mathrm{ppm}$ for the protons $(4 \mathrm{~B})-\mathrm{H}^{1},(4 \mathrm{~B})-\mathrm{H}^{2}$ was observed (Figure 3 ). At the same time the intensity of the doublet at $\delta 5.80 \mathrm{ppm}$ of the proton $(4 \mathrm{~A})-\mathrm{H}^{9 \prime}$ and singlet at $\delta 6.1 \mathrm{ppm}$ for the proton $(4 \mathrm{~A})-\mathrm{H}^{3 \prime}$ was decreased. The data obtained indicate that the equilibrium is shifted to the merocyanine form due to the formation of complex (5) (Scheme 2). The content of the merocyanine form involved into the complexation with $\mathrm{Mg}^{2+}$ ion was estimated as $\sim 83 \%$ (1 hour after salt addition).

The absorption at $480 \mathrm{~nm}$ (Figure 4) was chosen to determine the composition of the complex by the method of molar ratios [21]. The molar ratios plot shown in Figure 4 makes it evident that the composition of the $(4 \mathrm{a})-\mathrm{Mg}^{2+}$ complex is $2: 1$.

\section{Conclusions}

Novel photochromic spiropyrans containing 6'-hydroxy group in solutions exist as equilibrium mixture of spirocyclic and merocyanine isomers. The addition of metal salts leads to formation of complexes with merocyanine isomers and shifts the equilibrium to the ring-opened forms. The results obtained indicate that binding of cations is an important factor affecting position of the spyropyranmerocyanine equilibrium. These ionochromic compounds can be used as the basis for design of chemosensors for metal ions.

\section{Acknowledgments}

This work was supported by Russian Foundation for Basic Research (grants N 09-03-00052, 07-03-00234, and 0903-00813), Ministry of Education and Science of Russian Federation (grant N RNP2348), "Russian Science Support Foundation" and and President's of RF grant (NSh363.2008.3). 


\section{References}

[1] A. O. Bulanov, L. D. Popov, G. I. Bondarenko, and V. A. Kogan, "New binuclear copper(II) complexes with bishydrazones derived from spiropyran of the benzoxazinonium series," Russian Journal of General Chemistry, vol. 76, no. 8, pp. 1272 1274, 2006.

[2] A. O. Bulanov, B. S. Luk'yanov, V. A. Kogan, and V. V. Lukov, "Binuclear copper(II) complexes with hydrazones containing spiropyran fragment," Russian Journal of Coordination Chemistry, vol. 29, no. 9, pp. 658-659, 2003.

[3] X. Guo, D. Zhang, and D. Zhu, "Photocontrolled electron transfer reaction between a new dyad, tetrathiafulvalenephotochromic spiropyran, and ferric ion," Journal of Physical Chemistry B, vol. 108, no. 1, pp. 212-217, 2004.

[4] M. V. Alfimov, O. A. Fedorova, and S. P. Gromov, "Photoswitchable molecular receptors," Journal of Photochemistry and Photobiology A, vol. 158, no. 2-3, pp. 183-198, 2003.

[5] K. Kimura, H. Sakamoto, and M. Nakamura, "Molecular design and applications of photochromic crown compounds-how can we manipulate metal ions photochemically?" Bulletin of the Chemical Society of Japan, vol. 76, no. 2, pp. 225-245, 2003.

[6] A. M. A. Salhin, M. Tanaka, K. Kamada, et al., "Decisive factors in the photoisomerization behavior of crowned spirobenzopyrans: metal ion interaction with crown ether and phenolate anion moieties," European Journal of Organic Chemistry, no. 4, pp. 655-662, 2002.

[7] N. Shao, Y. Zhang, S. Cheung, et al., "Copper ion-selective fluorescent sensor based on the inner filter effect using a spiropyran derivative," Analytical Chemistry, vol. 77, no. 22, pp. 7294-7303, 2005.

[8] B. G. Jeliazkova, S. Minkovska, and T. Deligeorgiev, "Effect of complexation on the photochromism of $5^{\prime}$-(benzothiazol-2yl)spiroindolinonaphthooxazines in polar solvents," Journal of Photochemistry and Photobiology A, vol. 171, no. 2, pp. 153160, 2005.

[9] A. V. Chernyshev, N. A. Voloshin, I. M. Raskita, A. V. Metelitsa, and V. I. Minkin, "Photo- and ionochromism of 5'-(4,5-diphenyl-1,3-oxazol-2-yl) substituted spiro[indolinenaphthopyrans]," Journal of Photochemistry and Photobiology A, vol. 184, no. 3, pp. 289-297, 2006.

[10] N. A. Voloshin, A. V. Chernyshev, A. V. Metelitsa, I. M. Raskita, E. N. Voloshina, and V. I. Minkin, "Synthesis of photochromic 5'-(4,5-diphenyl-1,3-oxazol-2-yl)-spiro[indoline2,3'-naphtho[2,3-b] pyran]," Russian Chemical Bulletin, vol. 54, no. 3, pp. 705-710, 2005.

[11] R. A. Kopelman, S. M. Snyder, and N. L. Frank, "Tunable photochromism of spirooxazines via metal coordination," Journal of the American Chemical Society, vol. 125, no. 45, pp. 13684-13685, 2003.

[12] J. D. Winkler, C. M. Bowen, and V. Michelet, "Photodynamic fluorescent metal ion sensors with parts per billion sensitivity," Journal of the American Chemical Society, vol. 120, no. 13, pp. 3237-3242, 1998.

[13] N. A. Voloshin, A. V. Chernyshev, A. V. Metelitsa, et al., "Photochromic spiro[indoline-pyridobenzopyrans]: fluorescent metal-ion sensors," Archive for Organic Chemistry, vol. 11, pp. 16-24, 2004.

[14] M. S. Attia, M. M. H. Khalil, M. S. A. Abdel-Mottaleb, M. B. Lukyanova, Yu. A. Alekseenko, and B. Lukyanov, "Effect of complexation with lanthanide metal ions on the

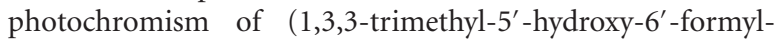
indoline-spiro $2,2^{\prime}-[2 \mathrm{~h}]$ chromene) in different media,"
International Journal of Photoenergy, vol. 2006, Article ID 42846, 9 pages, 2006.

[15] Z. Liu, L. Jiang, Z. Liang, and Y. Gao, "Photo-switchable molecular devices based on metal-ionic recognition," Tetrahedron Letters, vol. 46, no. 5, pp. 885-887, 2005.

[16] A. Abdullah, C. J. Roxburgh, and P. G. Sammes, "Photochromic crowned spirobenzopyrans: quantitative metal-ion chelation by UV, competitive selective ion-extraction and metal-ion transportation demonstration studies," Dyes and Pigments, vol. 76, no. 2, pp. 319-326, 2008.

[17] M. Tanaka, K. Kamada, H. Ando, T. Kitagaki, Y. Shibutani, and K. Kimura, "Synthesis and photochromism of crowned spirobenzothiapyran: facilitated photoisomerization by cooperative complexation of crown ether and thiophenolate moieties with metal ions," Journal of Organic Chemistry, vol. 65, no. 14, pp. 4342-4347, 2000.

[18] R. T. F. Jukes, B. Bozic, F. Hartl, P. Belser, and L. de Cola, "Synthesis, photophysical, photochemical, and redox properties of nitrospiropyrans substituted with $\mathrm{Ru}$ or Os tris(bipyridine) complexes," Inorganic Chemistry, vol. 45, no. 20, pp. 8326-8341, 2006.

[19] V. V. Korolev, D. Yu. Vorobyev, E. M. Glebov, et al., "Spironaphtoxazines produced from crown-containing dihydroisoquinolines: synthesis and spectroscopic study of cationdependent photochromism," Journal of Photochemistry and Photobiology A, vol. 192, no. 2-3, pp. 75-83, 2007.

[20] V. Lokshin, A. Samat, and A. V. Metelitsa, "Spirooxazines: synthesis, structure, spectral and photochromic properties," Russian Chemical Reviews, vol. 71, no. 11, pp. 893-916, 2002.

[21] M. Beck and I. Nagypal, Chemistry of Complex Equilibria, Academiai Kiado, Budapest, Hungary, 1989. 


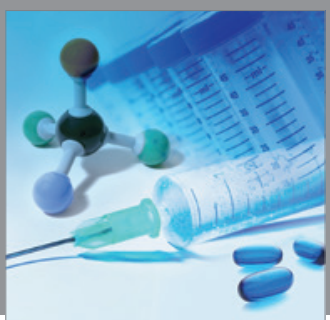

International Journal of

Medicinal Chemistry

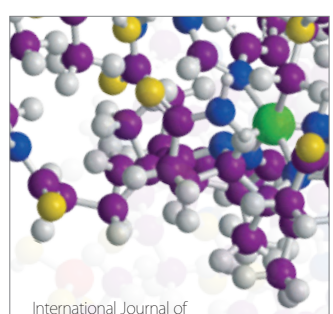

Carbohydrate Chemistry

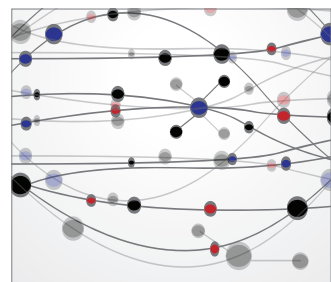

The Scientific World Journal
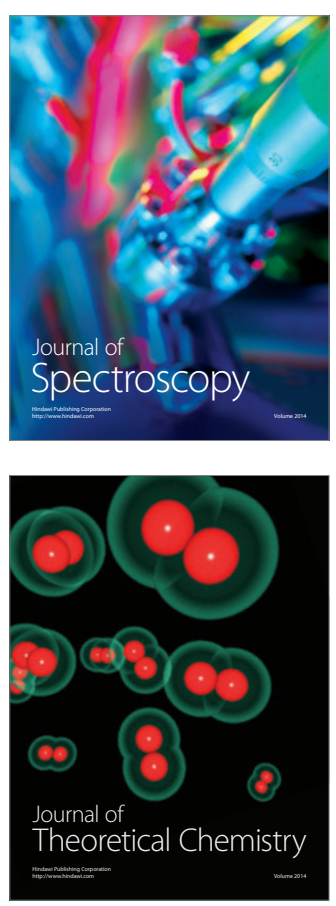
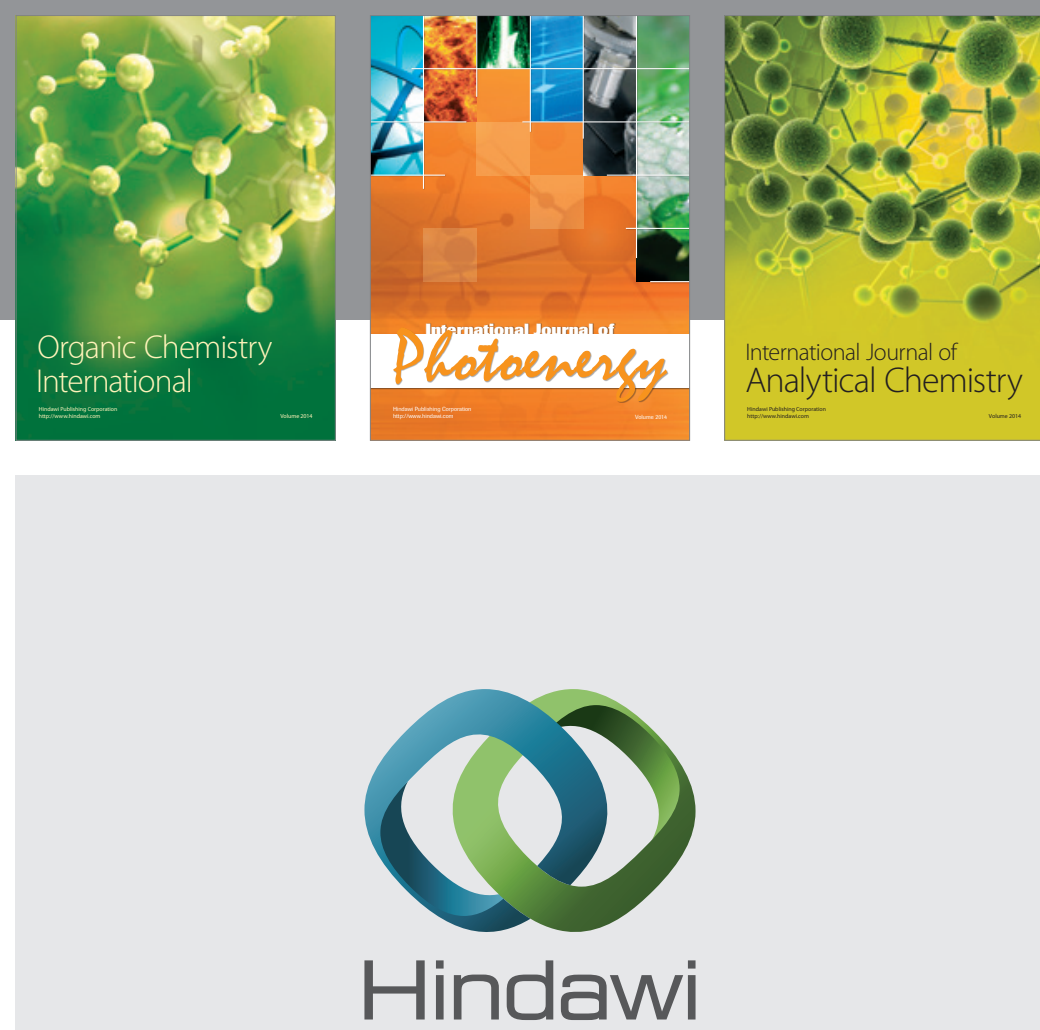

Submit your manuscripts at

http://www.hindawi.com
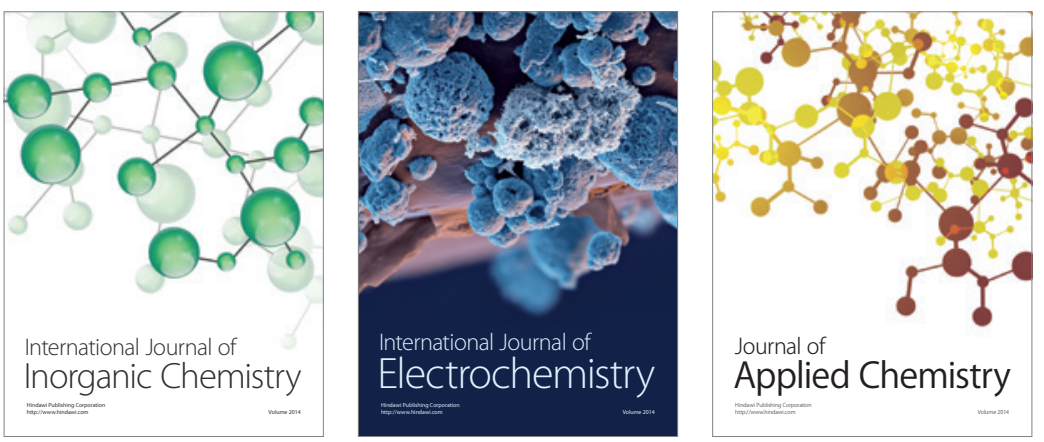

Journal of

Applied Chemistry
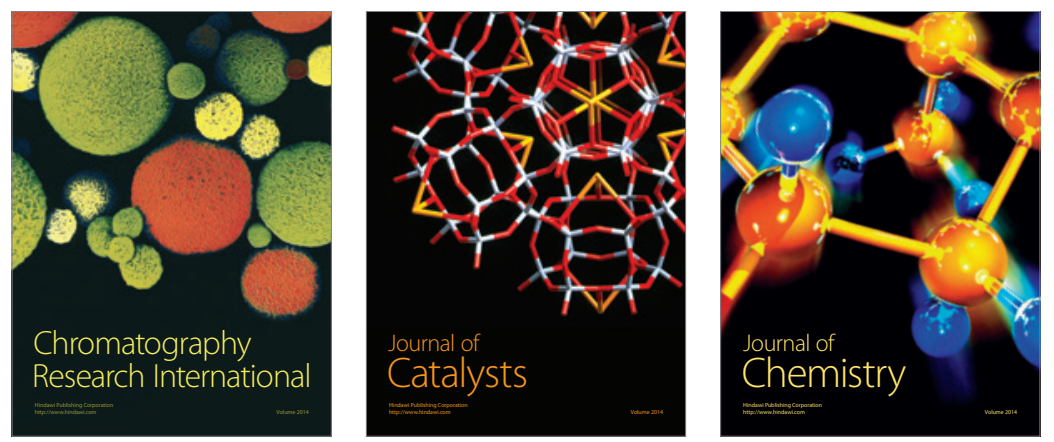
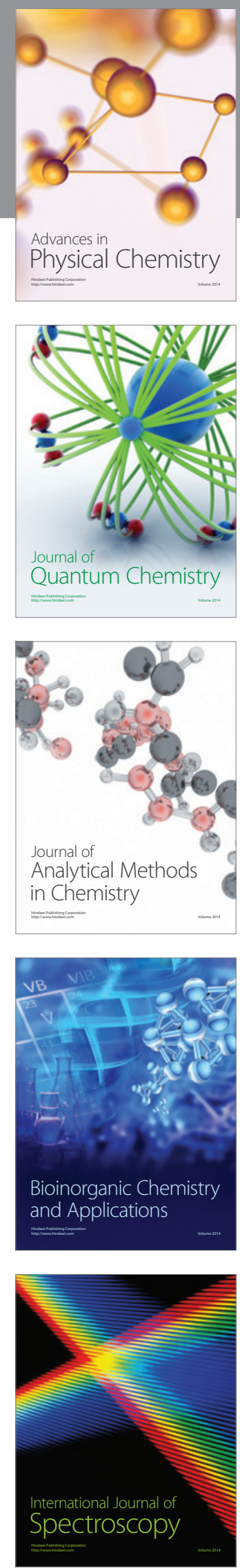